\title{
Improving the Delivery of a Construction Management Study-Abroad Course in Ireland through Student Feedback
}

\author{
James L. Jenkins and Robert F. Cox \\ Purdue University, West Lafayette, Indiana \\ United States of America
}

\author{
James O’Connor and Sonya Meekel \\ Dublin Institute of Technology \\ Dublin, Republic of Ireland
}

\author{
Jamie Goggins \\ National University of Ireland, Galway \\ Galway, Republic of Ireland
}

\begin{abstract}
International study abroad offers limitless opportunities for students to learn outside of the traditional university setting. By living and learning in a foreign country, the student's exposure to a different culture can help them experience history first-hand and discover new ways of thinking/living. Recent trends show that the number of U.S. college students participating in study-abroad courses offered by their university is increasing. Apart from the exposure to different cultures, many studyabroad courses do not provide a focused subject area related to a discipline of study chosen by the individual student. This paper describes an overall view of an international construction management study-abroad course conducted in Ireland by both American and Irish faculty members. The results of student surveys that were used to assess the course learning objectives and provide suggestions for improvement are also presented. These suggestions can be used by faculty members to develop or improve a similar construction-focused study-abroad courses.
\end{abstract}

\section{Introduction}

Results of a survey conducted by the Institute of International Education (IIE) showed that the participation levels of U.S. college students in study abroad programs were on the rise in 2010 and 2011 for the second straight year. More than half of the universities (53 percent) responding to the IIE survey indicated an increase in the number of their students studying abroad [1]. This upsurge is attributed to the increased interest of many college students wanting to gain an international experience during their undergraduate careers in order to further their future careers [2]. Employers in the international market are always looking for talents and characteristics that set candidates apart, particularly those leaders that are able to embrace cross-cultural differences [3]. This is especially true with construction management students as construction markets become more globalized. As the global market for construction expands, the demand for construction professionals willing and equipped to work in an international environment will also increase [3]. Therefore, to help aid their careers, students must possess broad international knowledge and strong intercultural skills in dealing with the cultural differences of multiethnic work forces [3, 4]. This impacts universities because it influences what students should be taught in order to prepare them to be able to communicate and work with people from other cultures and countries [5]. Many colleges offer a wide range of study abroad options as educators try to globalize their curriculums [6]. However, while the wide variety of options may satisfy students' desires to travel internationally, it may not fulfill needs specifically required for career development of students. The Purdue University Department of Building Construction Management (BCM) provides a career-specific study abroad course that offers many opportunities for students to learn about construction, while traveling internationally. To help determine if the construction-focused study-abroad course meets the course purposes, and the needs and expectations of the students, the Purdue University students involved with the 2010 and 2011 Ireland Study Abroad programs were surveyed. These surveys have provided feedback for the improvement of future study abroad courses. This paper presents an overall view of the International Construction Management in Ireland Study Abroad program, and the results of the student surveys conducted for the 2010 and 2011 courses. Faculty members can take the lessons learned from the information obtained in the student surveys to develop or improve similar career-focused study abroad courses. 


\section{Method of the BCM Study-Abroad Program}

From its early Celtic roots to its Viking settlements, and through medieval construction and Georgian-style architecture, the Republic of Ireland offers one the chance to visit a variety of historic structures. Along with its rich cultural history, Ireland's membership in the European Union provides excellent opportunities for American students to study European business practices, politics, and society [7]. Additionally, Ireland is an English-speaking country and has many universities offering construction-related curricula such as construction management, civil engineering, and architecture. Therefore, with all of these positive factors, Ireland was chosen as the location for this series of BCM International Courses, which was named the International Construction Management in Ireland Study Abroad course.

\subsection{Objectives of Course}

The main purpose of the two-week Ireland study-abroad course is to introduce American students to Irish construction practices and methods. This is accomplished by visiting new and historic construction sites across Ireland. Site visits are supplemented by lectures given by industry professionals, and by Irish and American faculty members. Another course goal is to educate students on the history and culture of Ireland. This is accomplished through pre-course and course research, course visits to popular tourist destinations, and interaction with local Irish citizens.

In order to help facilitate learning opportunities during the course, a majority of the research is conducted by students prior to leaving for the studyabroad course in Ireland. Study-Abroad students meet for three two-hour class sessions in the month prior to the course to discuss the itinerary and destinations of the upcoming course. Students are also assigned research topics (as chosen by the instructor) during these pre-course class meetings. Research topics reflect important points of history or upcoming course-trip destinations. Each student prepares a10-minute PowerPoint presentation on their assigned research topic which is presented to the other members of the class during the pre-course class meetings. As a result, each becomes the course expert and depository of knowledge on their assigned research topic for the other students while on location in Ireland. A sampling of research topics presented by the 2010 and 2011 students includes Georgian-style architecture, Gothic cathedral construction; Irish history; General Oliver Cromwell; popular tourist sites to visit in the cities of Dublin, Cork, and Galway; and Ireland's fight for independence. Students are also required to maintain a written journal of their daily activities during the two-week course-trip around Ireland. The format for each day of the Ireland Study-Abroad Journal is to provide a brief description of the day's activities, whom they meet that day, construction-related knowledge gained, Irish phrases and terms learned, something about themselves learned, and one thing they will never forget about that particular day.

The 2010 and 2011 course journals were submitted to the instructor at the conclusion of the courses. Not only did the journals serve as an assessment tool, but were also used as a compilation of all of the activities and learning points in which the students participated and discovered.

\subsection{Course Itinerary}

The two-week courses for 2010 and 2011 originated in the capital city of Dublin, From there, course travel included the cities of Cork, Limerick, and Galway before returning to Dublin for the final days of the two-week course. This allowed students and faculty to purchase round-trip airfare to-andfrom Dublin's International Airport, which has air flights to-and-from major U.S. cities. A summary of the two-week course itinerary is shown in Table 1.

Table 1. Course itinerary summary

\begin{tabular}{|l|l|}
\hline DAYS 1-3: DUBLIN & DAYS 4-6: CORK \\
\hline Bus Tour of Dublin & University of Cork \\
Guinness Brewery & Walking Tour of Cork \\
Dublin Institute of & Site Visit with Jacobs \\
Technology (DIT) & Engineering \\
Mater Hospital & City of Cobh Waterfront \\
Construction Site Visit & Blarney Castle / Blarney \\
Henrietta Street & Stone \\
Renovation & \\
Christ Church Cathedral & \\
\hline DAYS 7-8: & DAY 9: BURREN \\
\hline LIMERICK/BUNRATTY & AREA/CLIFFS OF \\
\hline CASTLE & MOHER \\
\hline Bunratty Castle Tour & Bus Tour of Burren Area \\
Walking Tour of Bunratty & Caher Connell Stone Fort \\
Folk Park & Poulnabrone Portal Tomb \\
Medieval Banquet in & Blackhead (Galway Bay) \\
Bunratty Castle & Cliffs of Moher \\
Durty Nelly's Pub & \\
\hline DAYS 10-11: & DAYS 12-14: DUBLIN \\
\hline GALWAY/ARAN & Jameson Distillery \\
\hline ISLANDS & City of Howth Harbor \\
\hline National University of & St. Patrick's Cathedral \\
Ireland (NUI) & Book of Kells \\
Walking Tour of Galway & Dublin Castle \\
Galway Harbor & Brazen Head Pub \\
Renovation Project & \\
Bike Tour of Aran Islands & \\
\hline
\end{tabular}




\section{Results from Student Feedback}

Continual improvement of one's teaching is an important factor in maintaining enthusiasm for teaching and improving teaching effectiveness [8]. The feedback may be obtained either through the use of questionnaires or through interviews with students.

Additionally, due to the short duration of time the students spend in Ireland, the lead instructor wanted to ensure that time isn't being “wasted” on an event/location which held little educational value or was not of interest to the students. Gathering student feedback on teacher practice and course content through surveys provided a valuable tool to use to help gauge the effectiveness of course topics.

To help evaluate student learning, and potential areas in need of improvement, a series of questionnaire surveys was taken by the students participating in the 2010 and 2011 Ireland Study-Abroad courses. These surveys consisted of both multiple-choice and open-ended questions. The Pre-Course Survey was conducted prior to the student's arrival in Ireland and a Post-Course Survey was completed at the conclusion of the two-week course. The surveys were voluntary and did not impact the students' grades for the course.

After the results of the surveys were compiled, both positive and negative comments/ratings were reviewed in order to find strong and weak points. Any event/location listed in the strong points/positive comments were to be replicated in future courses while any identified weak areas would be evaluated for possible improvement or removal from the course content [8]. The results of each survey are provided in the following sections.

\subsection{Pre-Course Survey Results}

The Pre-Course Survey dealt with general study-abroad information and was estimated to take students twenty minutes to complete. Eight of ten students responded from the 2010 course, with thirteen of thirteen responding from the 2011 course. From the 21 respondents, the following information was obtained: One item questioned the students about their previous international travel. Thirteen students (62 percent) responded that they had traveled abroad prior to the Ireland Study-Abroad course. The popular countries visited were Canada (6 students), Mexico (6 students), Italy (5 students), England /United Kingdom (4 students), and France (4 students). Each of those students indicated that they had traveled to multiple countries previously, including Israel, China, Greece, Australia, and Jamaica (1 student each). Twelve of the students indicated that their travel had been for vacation, while three trips were to visit relatives (1 student), as part of a school trip (1 student), and as part of a mission team (1 student). Fifteen students already possessed passports, one student had to renew his passport prior to leaving for Ireland, while the remaining five students ordered their passports for the first time.

Students were asked to rank a list of reasons why they chose to participate in the International Construction Management in Ireland Study-Abroad course. These reasons included the cultural experience of the course, personal enrichment, resume building, learning international construction methods, to have fun, or to have the experience of a lifetime. Rankings were given numerical values on a five-point scale; where 1=extremely important, $2=$ very important, $3=$ =moderately important, $4=$ slightly important, $5=$ not as important, and $6=$ no importance. Overwhelmingly, the students indicated that the culture experience of the course was the main reason with an overall average ranking of 1.81 (ranked 1.75 for 2010 students and 1.85 for 2011 students). The reason ranked second-highest was their interest in learning about international construction methods (mean=1.90; ranked 1.88 for 2010 students and 1.92 for 2011 students). There was a tie for the two reasons that were ranked as the third-highest rankings. These reasons were to have fun (mean=2.05; ranked 2.00 for 2010 students and 2.08 for 2011 students) and that the course was the experience of a lifetime (mean=2.05; ranked 2.00 for 2010 students and 2.08 for 2011 students). The study of a foreign language (mean=5.05; ranked 5.00 for 2010 students and 5.08 for 2011 students) and using the course for resume building (mean=2.81; ranked 2.25 for 2010 students and 3.15 for 2011 students) were the two reasons that received the lowest rankings for both groups of students. One 2010 student indicated that he used the course to evaluate his desire to study in Ireland for the Spring 2011 semester, and one 2011 student indicated that he wanted to see his family's ancestral home.

Students were also asked to rank the importance of factors that ultimately affected their decision to participate in the course. These deciding factors included the educational content of the course, cost of the course, travel to an English-speaking country, course itinerary, travel to an American-safe country, dates of the course, duration of the course, exciting places to visit, room accommodations, and scheduled free time for the students. Rankings were given numerical values on a five-point scale, where $1=$ extremely important, 2=very important, $3=$ moderately important, $4=$ slightly important, $5=$ not as important, and 6=no importance. Students in the 2010 class indicated that the course was exciting (ranking of 2.00), dates of the course (ranking of 2.38), and educational content (ranking $=2.50$ ) of the course were the top-three deciding factors. The 2011 students indicated that the fact that Ireland was "American-friendly" country and that the course was 
exciting (both received a ranking of 1.92) and the educational content of the course (ranking $=2.00$ ) also helped them decide whether or not to participate in the course. Surprisingly, the cost of the course received the second-least deciding factor with an overall ranking of 2.86 (2.75 for 2010 students and 3.17 for 2011 students). Room accommodations were ranked as the lowest of deciding factors for both groups, with a mean score of 3.29 (3.63 for 2010 students and 3.33 for 2011 students). Two students indicated they had always wanted to visit Ireland due to their family's Irish heritage.

\subsection{Post-Course Survey Results}

After spending two-weeks in Ireland, students were asked to respond to a post-course survey. The results from this post-course survey were used to evaluate the learning objectives of the study-abroad course. Eight students from the 2010 course, and nine students from the 2011 course answered the survey. The first question on this survey asked the students to describe their view of the construction industry in Ireland. Many of them stated that they were surprised by the magnitude of the bad economic conditions worldwide, and of the especially severe effect on the construction industry in Ireland. One student stated that he was, "discouraged," by the large amount of abandoned jobsites around Ireland. Another student said that, "After seeing all of the abandoned projects and tower cranes no longer in use and the mass amount of individuals no longer applying for the DIT apprenticeship program, it gave me a realization of how bad the construction industry in Ireland was hurting. Even the Irish professors pointed out that this was normal for students to leave the country after they graduate just to find work."

However, students were impressed by the professionalism displayed by the Irish contractors and the use of high-tech methods in the midst of the bad economy. The 2010 students were especially mesmerized by the bubble-slab system used on the new engineering building at the National University of Ireland in the city of Galway. The 2011 students had the opportunity to tour the newly opened engineering building the following year, and came away impressed by the completed project. The use of the concrete pumping system used on the Mater Hospital project in the city of Dublin and how it was integrated into the design of the building was a construction method that was fascinating to the students. One student stated that he was impressed with the construction trades training program at DIT. He went on to say that the American construction industry could benefit from a similar program as it would increase the quality of skilled-craftwork and increase the knowledge of tradespersons.
The attention to detail for the safety of Irish construction workers was another point that made an impression on the students. Many students left Ireland with the opinion that the level of safety is higher on Irish jobsites when compared to American counterparts. This could be attributed to the fact that all of the construction jobsites visited during the study-abroad courses required students to sit through a site-specific safety orientation prior to allowing them on-site. These sites also required employees and visitors to not just wear hardhats, but also safety glasses, steel-toed work boots, and high-visibility safety vests as well. Some jobsites further required everyone on the project to wear protective gloves. The cleanliness of the Irish jobsites also impressed the visiting American students. The use of stackable office trailers by Irish contractors was deemed by students to be very useful on American jobsites with limited storage space on the project site.

The students were also amazed at the extent of the recycling of construction waste materials on the jobsites in Ireland. The widespread use by construction workers of separate bins or dumpsters for sorting out metal, wood, and paper material on jobsites in Ireland, and the lack of such methods in the United States, was noted by the study-abroad students. Students also found that the renovation of historical structures was more organized and appeared to be more prevalent in Ireland than in the United States. Where Americans seem to tear down older structures to make way for more modern versions, the students wrote that the people of Ireland seem to care more about the preservation of their historic buildings and the significant status that these structures possess in Irish history. One student realized that many of the buildings visited during the course were older than the United States. This was especially true of the Georgian-style terrace homes on Henrietta Street in the city of Dublin, many of which were built in the mid-1700s. After course site visits in 2010 and 2011 to one of the recently renovated buildings on Henrietta Street, students stated that they were impressed by the care and patience that was taken by the designer, engineer, and contractor in order to leave the building as original and authentic as possible. The large amount of preplanning undertaken by Irish construction teams prior to renovation activities to ensure the structural stability of the building also left a favorable impression on the students.

When students were asked how their perception of the world outside the borders of the United States was changed after spending two weeks in Ireland, most students stated that the course "opened their eyes" to a world of different cultures and traditions. It also helped students see that the United States is not the only country affected by the current poor economic conditions. The course also made one student realize that there are a lot of opportunities 
available to American citizens in the United States. Many of these opportunities are often taken for granted and aren't readily available to citizens in other countries. The fact that many Irish students have to look beyond the borders of Ireland for a job after they graduate really hit home with the American students.

Overall, the course inspired a few study-abroad students to travel back to Ireland with close family and friends. One student plans to return to Ireland with his friend as a mutual graduation present to each other. Because of the positive experience of the study-abroad course, one student from the 2010 course actually spent the full Spring 2011 semester studying at DIT as part of a student exchange. Three other students said that the course to Ireland gave them the desire and courage to travel and see the rest of the world.

\section{Future Course Changes}

To further facilitate improvements for future study abroad trips to Ireland, students were asked to rate the locations they visited during their coursetour of Ireland. Specific construction site visits were not surveyed since they change from year-to-year. The cities of Dublin, Cork, and Galway were also left off the survey as they will remain as a constant core of the study abroad itinerary. The locations surveyed were included on both the course itineraries for the 2010 and 2011 study abroad courses.

Students rated each of these items based on a 5point scale: 5= excellent, 4=very good, 3=good, $2=$ fair, 1 =poor, and $0=$ not applicable/did not attend. A score for each of the locations surveyed is included in Table 2.

Table 2. Student ratings of course locations

\begin{tabular}{|c|c|c|c|}
\hline Location & $\begin{array}{c}\text { Year } \\
2010\end{array}$ & $\begin{array}{c}\text { Year } \\
2011\end{array}$ & $\begin{array}{c}2010 \& \\
2011 \\
\text { Combined }\end{array}$ \\
\hline Aran Islands & 4.50 & 3.11 & 3.76 \\
\hline Blarney Castle & 4.63 & 4.56 & 4.59 \\
\hline $\begin{array}{c}\text { Book of Kells } \\
\text { Bunratty Folk Park }\end{array}$ & 3.63 & 3.89 & 3.76 \\
\hline $\begin{array}{c}\text { Bunratty Medieval } \\
\text { Feast }\end{array}$ & 4.67 & 4.71 & 4.69 \\
\hline & 4.63 & 4.44 & 4.53 \\
\hline
\end{tabular}

\begin{tabular}{|c|c|c|c|}
\hline $\begin{array}{c}\text { Burren/Cliffs of } \\
\text { Moher }\end{array}$ & & & \\
\hline $\begin{array}{l}\text { Christ Church } \\
\text { Cathedral }\end{array}$ & 3.75 & 3.89 & 3.82 \\
\hline Cobh Museum & 4.00 & 4.40 & 4.25 \\
\hline City of Cobh & 5.00 & 4.80 & 4.91 \\
\hline City of Howth & 4.25 & 4.00 & 4.17 \\
\hline Dublin Bus Tour & 2.38 & 3.00 & 2.44 \\
\hline Dublin Castle Tour & 3.63 & 3.67 & 3.65 \\
\hline Guinness Brewery & 3.50 & 3.67 & 3.59 \\
\hline Henrietta Street & 3.00 & 2.33 & 2.65 \\
\hline Jameson Distillery & 4.00 & 4.11 & 4.06 \\
\hline $\begin{array}{l}\text { St. Coleman's } \\
\text { Cathedral }\end{array}$ & 5.00 & 4.60 & 4.82 \\
\hline $\begin{array}{l}\text { St. Patrick's } \\
\text { Cathedral }\end{array}$ & 3.75 & 3.44 & 3.59 \\
\hline
\end{tabular}

Based on the results, shown in Table 2, the highest ranked location was the city of Cobh with a mean score of 4.91 (5.00 for 2010 students and 4.80 for 2011 students). The course to Cobh was included as an optional day trip during a scheduled free time on the course itinerary for both the 2010 and 2011 courses. Comments made by the eleven students who visited the city of Cobh include the suggestion to make the Cobh trip a permanent part of the regular course itinerary for future classes. Visits to the St. Colman's Cathedral in Cobh (mean=4.91; rated 5.00 for 2010 students and 4.60 for 2011 students) and the Cobh Heritage Museum (mean=4.82; rated 4.00 for 2010 students and 4.40 for 2011 students) were also highly ranked. Other locations receiving high marks included the medieval feast at Bunratty Castle (mean=4.69; rated 4.67 for 2010 students and 4.71for 2011 students), the visit to Blarney Castle 
(mean=4.59; rated 4.63 for 2010 students and 4.56 for 2011 students), and the bus trip through the Burren Area/Cliffs of Moher (mean=4.53; rated 4.63 for 2010 students and 4.44 for 2011 students). The lowest rated locations on the 2010 course included the Henrietta Street renovation project (rated 3.00), the Book of Kells (rated 2.88), and the Dublin Bus tour (rated 2.38). The 2011 students rated the Book of Kells (rated 3.38), the trip to the Aran Islands (rated 3.11), and the visit to the Henrietta Street renovation project $(2.33)$ as the lowest rated locations. It should be noted that the Aran Islands trip received a high rating of 4.50 from the 2010 students. The huge difference between the widerange of ratings of the Aran Islands trip could be explained in one word: weather. The 2010 students enjoyed a beautiful sunny day with temperature ranging between 75-85 degrees F. On the other hand, the 2011 students spent most of the day on the Aran Islands under rainy conditions in 40-50 degrees $\mathrm{F}$ conditions.

A few of the 2010 and 2011 events received unfavorable ratings from the students. The tour at Henrietta Street received the most unfavorable mentions in the student surveys. While students wrote that they found the site visit interesting, it appears that they thought the presentation and actual site tour took too long. The visit to the Aran Islands was included by a 2011 student on the unfavorable list. The student explained that the low rating was due to the inclement weather, bicycle malfunction, and pure exhaustion. The hostel where the students spent nights in the city of Galway was listed by a 2010 student as unfavorable. Unfortunately, the hostel was also being used by a large group of elementary-aged students who were not being supervised sufficiently. As a side note, the 2011 group stayed in the same hostel the following year without experiencing similar problems.

\section{Discussion of the Overall Survey Results}

The pre-trip survey results show that the top-2 reasons students chose to participate in the study abroad course were to experience the culture of Ireland and learn about international construction methods. This data is encouraging as the two reasons given by the students match perfectly with the two main objectives determined by the lead instructor of the International Construction Management in Ireland study abroad course. Students also indicated that the course itself was "exciting" (often based on experiences from past student participants) and that the timing of the course (which occurs directly after the end of the university's spring semester) along with the educational content were factors that ultimately led students to enroll in the class. It should be noted that the timing of the Ireland study abroad trip allows BCM students to participate in this course and still allow time for them to fit in their summer work internships with construction contractors. A big surprise to the authors was that the survey data indicated that the cost of the trip was ranked very low as a deciding factor on student's desire to enroll or not in the course.

Post-trip survey data provided encouraging information that the two main course objectives were met. Survey data indicates that students came away from Ireland impressed with the new ideas of engineering and construction methods used on Irish jobsites. The bubble-slab system at NUI-Galway and the built-in concrete pumping system at the Mater Hospital project in Dublin made a lasting impression on the students. Additionally, the high level of worker safety and the extent to which Irish contractors recycle used materials/waste were also major learning points of the jobsite visits. The care and patience taken during the preservation of historic structures in Ireland also left a good impression on the students. Even though the course has a construction focus, it is the fun, Irish cultural events/tours continues to be a main attractor of getting students interested in the course.

\section{Potential Course Revisions Based on Student Feedback}

To help evaluate which course events and/or locations to either keep or remove from future study abroad courses, students were asked to list and explain the one study-abroad event or location they liked the best, and to list and explain one event or location they liked the least. As indicated by the results in Table 2, the students really enjoyed the day course to the city of Cobh and the scenic views around the city. They also mentioned that they learned more things pertaining Irish immigration and naval history in the Cobh Heritage Museum than in history class. Attending the medieval feast in an actual castle (Bunratty Castle), and listening to traditional music both during the dinner and afterwards at the Durty Nelly's pub near Bunratty Castle, were listed multiple times as the best event in the surveys. The natural beauty of the Cliffs of Moher was also listed as a location best liked by students. The cities of Dublin, Cork, Galway, and the Aran Islands were also each listed as a favorite location.

As shown in Table 2, it comes as no surprise that students listed the site visit to Henrietta Street as one of the least liked events. The low score given by the students to the Dublin Bus tours also marked this event as a potential deletion from the course.

The survey also asked students to provide suggestions for changes for future study-abroad courses in Ireland. A majority of the students 
suggested that the optional day course to Cobh and the Bunratty medieval dinner become a permanent, required part of the course. Scheduling a bus tour similar to the one taken through the Burren Area/Cliffs of Moher was also suggested to be included into the course itinerary for other parts of Ireland. It was also suggested that the study-abroad course begin in Galway and end up in Dublin to help eliminate some of the travel days. One student stated that he would be willing to pay more money to stay in hotels instead of hostels. Another student suggested that the museums and art galleries in Dublin be included on the course itinerary. A scheduled trip to some sort of athletic event was also suggested. These suggestions were evaluated to modify future the study abroad courses to Ireland conducted by the BCM Department at Purdue University.

\section{Actual Modifications to Course}

Although the Ireland Study Abroad course is successful in meeting its objectives, the lead instructor will revise the course on a continual basis to improve the learning experience of the students. The results of the student evaluations were not only used by the lead instructor to evaluate the achievement of the course learning objectives, but they were also used to revise course content. It is hoped that recommendations received from the previous students will improve student learning opportunities of future course offerings.

Modifications for the 2012 course included replacing the low-rated Henrietta Street visit with a trip to the Natural History museum in Dublin. The elimination of the Dublin Bus tour was used to facilitate the addition of free time for the students to explore the City of Dublin. Additionally, the hostel accommodations in Cork were switched to a Bed \& Breakfast. Since attending a sports event was very important, a Irish national soccer (i.e. European football) match was scheduled into the 2012 students were able to attend a Irish national soccer (i.e. football) match that was scheduled into the course itinerary. Feedback provided by the 2012 group of students via their trip journal was very positive towards these course improvements.

\section{Lessons Learned}

The feedback received from the students was a valuable tool in evaluating course content and determining whether or not course objectives had been met. When viewing student feedback, it was important to look for patterns in students' comments and identify positive and negative trends. This was especially helpful in identifying areas where the difference in ratings given by students was vastly different from the perceptions of the lead instructor.
For example, as stated previously in this paper, the Henrietta Street conservation \& renovation project was not very well received by the students, but was one of the favorite sites of the lead instructor. Since students are only in Ireland for two weeks, the amount of time spent in Ireland needs to be used as wisely and effectively as possible. Each event/location should capture the interest of students. Without the analysis of the student surveys, the Henrietta site visit would have remained as a permanent fixture of the Ireland Study Abroad course.

The lead instructor also learned that a simple trip journal recording details of the various events \& locations visited by the students was a great way to record ideas for potential improvement areas of the course. Noting what content went well and what areas need changes will provide the basis for future course improvements.

\section{Conclusion}

Many employers are looking for potential employees who set themselves apart from their peers. Many U.S. college students want to gain an international experience during their undergraduate careers in order to help set them apart from their peers and to aid in their search for their future careers. Students in the Department of Building Construction Management at Purdue University have the chance to experience a foreign culture while gaining knowledge of international construction methods by participating in a focused study-abroad course related to their discipline of study.

Due to the short duration of time the students actually spend in Ireland, the lead instructor wanted to ensure that time was well-spent at events/locations which presented a construction-related or cultural lesson. Gathering student feedback on teacher practice and the course content through student surveys provided a valuable tool to use to help gauge the effectiveness of course topics. Student suggestions are evaluated for possible revisions in future course offerings.

Based on the student survey results, it appears that the main objectives of the course of introducing American students to Irish construction practices methods and to educate students on the history and culture of Ireland were successfully met. Students came back from Ireland with a large amount of knowledge of the Irish construction industry that they gained from jobsite visits and lectures. They also returned with a fond appreciation of the Irish culture and history.

The course also had a positive effect on the instructors. Many of the construction safety methods and techniques used by Irish contractors were incorporated back into the construction safety course taught by the lead instructor in the United States. 
Additionally, by working together and sharing ideas in conducting the study abroad trip, the instructors were able to foster personal \& professional relationships that expand beyond the borders of the Republic of Ireland and the United States.

Overall, using the information gained by the surveys, improvements will be made in the Ireland Study Abroad course that will contribute to its success in the future. By conducting a similar survey process on a continual basis, faculty members/study abroad leaders can improve their respective courses and help ensure the course remains pertinent to the educational needs of the students. The continual improvement of the course is an important factor in maintaining enthusiasm for teaching the course and provides methods to improve teaching effectiveness

\section{References}

[1] Institute of International Education (IIE). (2011). Top 25 destinations of U.S. study abroad students, 2008/09 2009/10. Open Doors Report on International Educational Exchange. http://www.iie.org/opendoors (Access date: 27 January 2012).

[2] Hartlen, S. (2011). Everyone can study abroad! An adviser's guide to short-term study abroad opportunities http://www.dus.psu.edu/mentor/2011/09/

everyone-study-abroad/ (Access date: 26 January 2012).

[3] Martinez, L. (2011). The study abroad advantage. Diverse Issues in Higher Education. http://diverseeducation.com/article/16719/ (Access date: 6 December 2012).

[4] Choudhury, I. (2001). Cross-Cultural Training of Project Personnel for Implementation of International Construction Projects by US Contractors. Journal of Construction Education, 6, No. 1, pp. 20-27.

[5] Paige, M. (2005). Internationalization of Higher Education: Performance Assessment and Indicators. Nagoya Journal of Higher Education, 5: 99-122. http://www.cshe.nagoya-u.ac.jp/ publications/journal/no5/08.pdf_(Access date: 30 October 2009).

[6] Kramer, S. W. (2004). The Evolution of a Faculty-Led Study-Abroad Class for Construction Management Students. International Proceedings of the Associated Schools of Construction, Brigham Young University http://ascpro0.ascweb.org/ archives/cd/2004/index.htm (Access date: 1 October 2011).

[7] EuroLearn website (2011). Study abroad in Ireland. http://www.eurolearn.org/ destinations/ireland/ (Access date: 10 January 2012).

[8] University of Maryland University College website (2006). Using student feedback to improve your teaching. http://deoracle.org/onlinepedagogy/assessment-feedback-rubrics/using- student-feedback-to-improve-your-teaching.html (Access date: 25 October 2012). 